\title{
Globalisation, Economic Policy and the New Dualism in the South African Economy
}

\section{Gavin Maasdorp}

Emeritus Professor, Department of Economics, University of Natal, Durban

\section{ABSTRACT}

Economic dualism in South Africa has mutated from the original modern vs. traditional sector conception to one of poverty $v s$. non-poverty. Globalisation provides opportunities to reduce poverty, but government policies determine the outcome. The South African government's sound macroeconomic policies have not been matched on the micro side. The labour market has not been liberalised, employers are loath to increase staff numbers, and foreign investment in labourintensive industries is not being attracted. The policy choice is one of lower real wages and more jobs or higher real wages and fewer jobs. The unemployed and those in absolute poverty would opt for the former, unionised labour for the latter. Policy reforms will be politically difficult, but without them the dual economy will persist.

JEL F 41

\section{INTRODUCTION}

This is a discursive paper, exploring, at the request of the editors, the implications of globalisation for economic dualism in South Africa. The paper argues that the nature of the dual economy has changed over the years, that openness and economic growth are necessary for poverty reduction, that it is government policies which determine whether or not a country and its people are able to use globalisation to improve their welfare, and that South Africa could have done better than it has to take advantage of the opportunities for faster growth and poverty reduction.

\section{ECONOMIC DUALISM}

\section{The Concept}

The notion of economic dualism was introduced into economic development literature by Boeke (1953). He divided economic activity into two types: that car- 
His was a sociological explanation, emphasising institutional differences. Traditional institutions would continue to persist, and western institutions would never completely absorb the traditional sector.

The concept of technological dualism was introduced by Hirschman (1958) and Higgins (1968) who referred to foreign enclaves of capital-intensive activities (mining and plantation economies) which do not transform the entire economy. The modern sector has fixed technical coefficients of production, and further technological advances favour capital-intensive methods. In the traditional sector technical coefficients are variable, enabling production to become increasingly labour intensive until all available land is cultivated and the marginal productivity of labour falls below zero. This results in disguised unemployment. Thus, the gap between the two sectors widens progressively.

Lewis talks of a "capitalistic" and a "subsistence" sector. The former is "that part of the economy which uses reproducible capital and pays capitalists for the use thereof" (1954: 146); the latter is "all that part of the economy which is not using reproducible capital" (1954: 147). These two sectors exhibit a striking contrast in economic and social organisation. This type of dualism is marked by underemployment, disguised unemployment and a labour-surplus economy. Lewis (1954) developed a model of such an economy, as did Fei and Ranis (1964). The subsistence sector is agricultural in nature, relatively large and slow-growing, and wage rates are determined by institutional forces. By contrast, the modem (commercial and industrial) sector, although relatively small, is rapidly growing, wage rates being determined by competitive forces. In the labour-surplus economy, labour is abundant and capital scarce. The expanding modern sector draws labour from the traditional sector.

In practice, this interaction has not been robust enough to prevent growing urban unemployment. This is explained by higher-than-anticipated rates of population growth and the resultant high rates of rural-urban migration. In a celebrated model developed by Todaro (1971), migrants move to urban areas on the mere expectation of obtaining wage employment. In reality, what has happened is that urban unemployment and underemployment have grown, and so has the informal sector - a concept popularised by an ILO (1972) report on Kenya, and which continues to received considerable attention in the literature. The informal sector consists of unregistered and unrecorded activities whereas the formal sector consists of recorded activities in the wage economy. The original, neat distinction between traditional and modern sectors has been fudged by these trends, and today problems of open unemployment, underemployment, inadequate incomes and low productivity are found in urban as well as rural areas. 


\section{Its Relevance Today}

Horwood $(1964,1965)$ attempted to apply the concept of dualism to the South African economy. He found that the subsistence sector appeared to be expanding, and that it had not been reduced as a result of industrialisation. He felt that a subsistence element might eventually tend to creep into the modern sector. That is indeed what occurred with rapid rural-urban migration and the rise of the informal sector (Maasdorp \& Humphreys, 1975), exacerbated by relative economic stagnation from 1975 onwards.

In fact, the concept of a dual economy, with watertight compartments, has become increasingly inadequate as a tool of analysis not only in South Africa but also in neighbouring countries. For example, in Swaziland the majority of the population have been exposed to the modern industrial and commercial economy since the late-1800s, and "there is scarcely a household even in the remotest rural area that does not have (or has not had) some linkage with that economy" (Maasdorp 1991: 212). While working on nural projects in the Pongola flood plain and East Griqualand, the writer has encountered a similar situation. If the term economic dualism is to be used today, it would best be applied to a distinction between those in poverty and those not in poverty. But how does one calculate the cut-off between poverty and non-poverty?

The traditional way in South Africa was through measures such as the poverty datum line (PDL) which calculated the amount required to meet the minimum subsistence needs of an individual household, and then compared it to the monthly income of that household (Ellison et al., 1975). As such, the PDL was taken to be a measure of absolute poverty, meaning that a household below the PDL was unable to satisfy its bare subsistence needs. However, poverty is also a relative concept, referring to the extent of a household's resources in comparison to what other individuals or households in the society have. Relative poverty is assessed in relation to income distribution in the particular society: all those who fall below some arbitrary cut-off point, such as the lowest quintile, are then defined as poor. This method avoids the paternalism of subsistence measures which are calculated in money items, and demonstrates the income inequality rather than the economic survival aspects of poverty. Its main disadvantage relates to the reliability of income distribution data which are particularly suspect in countries with large rural subsistence or urban informal sectors. Clearly, though, it is the elimination of absolute rather than relative poverty which should be the priority of economic and social policy as that it is where the real heart of grinding poverty is found. 


\section{GLOBALISATION}

\section{Definition and Driving Forces}

The term "globalisation" is essentially a product of the 1990s. Collier (1998: 1) defines it as "the process of integration in product markets and financial markets". Calitz (2000: 564) offers a broader definition of economic globalisation, namely, as "the accelerated integration of economies throughout the world through trade, financial flows, the exchange of technology, information and ideas, and the movement of people".

In the last 30 years the growth of world trade has outpaced that of world GDP, partly as a result of policy changes and trade liberalisation which lowered trade barriers, and partly due to a technological revolution based on electronics which has led to falling communications costs. Together, these have changed the organisation of business worldwide, allowing the growth of transnational companies which account for about one-third of world output and two-thirds of world trade. Approximately one-third of world trade takes place within transnational corporations, i.e., between subsidiaries of the same corporation based in different countries.

\section{The Link with Poverty Reduction}

In a White Paper (HMSO, 2000) on globalisation, the British government states that it creates unprecedented opportunities for sustainable development and poverty reduction. Yet, globalisation has its enemies who regard it as a source of exploitation, poverty and inequality. The outcome depends on the policy choices adopted by govemments, international institutions, the private sector and civil society; if the new wealth being created by globalisation is managed wisely, it could lift millions of the world's poorest people out of their poverty; if it is managed badly, it could lead to marginalisation and impoverishment.

Africa's experience appears to substantiate this argument. Because of preferential access to EU and US markets, most of sub-Saharan Africa does not face the same trade barriers for its exports as do many other parts of the developing world, yet its share of total world trade has declined. Collier (1998) attributes Africa's current relative poverty mainly to its anti-trade policies: its economic policy environment has been hostile to foreign direct investment (FDI) in manufacturing industry which has been the most rapidly growing component of international trade.

Collier fits Africa into the Heckscher-Ohlin model: this posits that countries with abundant labour and scarce capital would have a comparative advantage in 
labour-intensive products. Thus, Africa should export labour-intensive goods, thereby increasing the demand for its labour and raising labour incomes. Its other options are labour emigration and an influx of capital. All these mechanisms should operate simultaneously and be poverty-reducing. However, transnational corporations, in shifting those production processes which do not require high levels of skilled labour to developing countries which have an abundance of unskilled labour, have bypassed Africa largely because of its poor policy environment. He contends that public expenditure has been directed more towards redistribution rather than infrastructure, whereas private capital prefers countries in which infrastructure is the priority for governments. We return to this point in relation to South Africa in Section 3.

The White Paper (HMSO, 2000: 17-18, 65-67) makes a number of important points:

(i) There is no evidence of a systematic relationship between openness and inequality, either between countries or within a country. It is policies of governments which determine whether inequality rises or falls. The poor sometimes gain more from trade, and sometimes less, than the average person.

(ii) There is no developed country which has a closed economy. Those poor countries which have successfully developed in recent decades - the East Asian newly industrialising economies (NIEs) - used open world markets to build strong export sectors and attract FDI. They invested massively in education, and the proportion of their populations living in poverty has fallen from 40 per cent to under 15 per cent in 40 years.

(iii) Trade liberalisation has been associated with more rapid economic growth, and has brought real benefits to consumers, including the poor. It has beneficial effects on productivity, the adoption and use of technology, and investment. The extent to which it contributes to poverty reduction, however, depends on broader economic and social circumstances as well as policies: trade openness is a necessary but not a sufficient condition for poverty reduction.

(iv) By contrast, the protectionist policies of the 1950 s and 1960 s in developing countries, following import-substituting industrialisation, were often associated with quite rapid growth, but unequally distributed gains. Often the poor were hurt by the urban bias against agriculture.

(v) There is also no systematic relationship between economic growth and inequality. Inequality has risen in some countries and fallen in others, no matter whether they have been fast- or slow-growing economies.

(vi) Economic growth is necessary for poverty reduction: the decline in the proportion of the population living in poverty has been largely the result of economic growth. In relation to (v) above, although the rich may gain more than the poor, the numbers in absolute poverty may fall. 
(vii) However, pro-poor development requires growth and equity, and poverty reduction is most rapid where growth is combined with declining inequality.

There has been increasingly strident criticism of globalisation from the late1990s onwards. The WTO and Bretton Woods institutions have come under fire for trade liberalisation and structural adjustment programmes which, it is claimed, have led to macroeconomic instability, unemployment and poverty. The international currency crisis of 1997.98 lent impetus to these criticisms.

In response, the Bretton Woods institutions and other aid agencies have revised their development programmes, realising that policy-making needs to include a pro-poor component in order to ensure that globalisation benefits poor people, especially in the longer term. Effective government and efficient markets are essential to attract FDI which will flow to where the climate for business is most favourable and least risky. Sound legal, institutional and regulatory frameworks, and the provision of key public and social services, are State responsibilities. Programmes now include the strengthening of public revenue and expenditure planning and management, and public expenditure programmes which target the poor through the satisfaction of basic needs.

A consequence of all this is that aid agencies are building pro-poor programmes into their project funding. Moreover, international development targets endorsed by the Bretton Woods institutions and the UN Millennium Summit in 1999 include a reduction by one-half in the proportion of people living in extreme poverty by 2015 , i.e., they focus on absolute poverty.

\section{What has happened in South Africa?}

South Africa's rapid economic growth between 1946-74 was also one of growing government intervention in the economy - a tendency which continued until into the 1980s. The South African government took a very different path from that of the East Asian NIEs, for example, Korea. Whereas in 1960 the two countries had roughly equal GDPs, by 2000 South Africa's was only one-third the size of Korea's GDP. Korea adopted open policies, but South Africa opted for import-substituting industrialisation behind high tariff barriers, delaying economic liberalisation until the early-1980s when some cautious moves on deracialisation of the economy and deregulation of sectors such as transport occurred. However, strict controls on capital movements were retained, and concerted tariff adjustments, centred around the Uruguay Round offer to GATT, were only implemented from 1995 onwards. The government from 1994 onwards relaxed but has not yet abolished exchange control, and has generally continued with liberal macroeconomic reforms. South Africa has always man- 
aged to be well integrated into the latest international telecommunications and information technology networks, and since 1994 its global trade network has expanded. Political change, with the lifting of sanctions and disinvestment pressures, meant an opening up of South Africa's trade far beyond its traditional partners, although these continue to be the major markets for exports and sources of supply for imports.

Economic dualism from the early 1970 s began increasingly to revolve around wage employment. Those without it were found in the urban informal as well as in the rural subsistence sectors. Bhorat (2001: 5) shows that formal employment fell between 1993-98 from about 7.8 million to 7.4 million. It increased only in the wholesale and retail trade and in financial and business services. Most of the losses occurred in the mining and construction industries, while manufacturing industry shed 50,000 jobs. The phase-down of tariffs from 1995 onwards under the WTO resulted in greater competitive pressures on manufacturing industry, output and investment levels in the sector falling. Trade liberalisation was accompanied by the increased adoption of new technologies, often in order to raise efficiency levels and to become more competitive, and capital-labour ratios rose. In public enterprises, job losses were the result of the restructuring programme, especially in the transport and telecommunications sectors.

Bhorat points to another trend noted above in relation to transnational corporations. Whereas the demand for skilled and highly skilled workers increased significantly, that for unskilled workers fell substantially. Thus, there is a new form of dualism in the labour market - a shortage of workers at the top end of the occupational ladder, and rising joblessness among unskilled workers. Although the fall in wage employment has been offset in part by the gain of 100,000 jobs in the informal sector, there are some 230,000 new entrants to the labour market each year (2000: 15). Official figures show a consistent decline in the index of non-agricultural employment since 1989. There are now two official estimates of unemployment: under the narrow definition the rate was 25.8 per cent in September 2000 whereas under the expanded definition (which includes discouraged job seekers) it was 35.9 per cent.

There is conflicting evidence about trends in inequality in South Africa. One study (BMR, 2000: 54) calculates that the disparities between rich and poor narrowed by one-half between 1991-96: the ratio of income of the richest 10 per cent and poorest 20 per cent of all households fell from 45:1 in 1991 to $22: 1$. However, South African inequality remains one of the highest in the world - the Gini coefficient was 0.63 (when 0 indicates complete equality and 1 extreme inequality). The narrowing in the gap between rich and poor was attributed by the BMR to a combination of affirmative action, the increased employment of Africans in the public service, and the equalising of welfare and pension pay- 
ments. By contrast, a survey (Statistics South Africa, 2000) found that inequality between the richest and poorest on the basis of pay increased between 1994-99. This was attributed to rising levels of unemployment.

The survey by Statistics South Africa (2000) found that 28.5 per cent of households were below the household poverty line of R 800 per month. The very poor, defined as those spending below R600 per month, accounted for 16.5 per cent of all households, while the comparable figure for those defined as poor (who spent between R600-1000 per month) was 24.8 per cent. Thus, 41.3 per cent of all households were poor or very poor. Because of a lack of time-series data, the study did not show poverty trends.

\section{SOUTH AFRICA - CAN GLOBALISATION BE BLAMED?}

\section{The Focus of Economic Policy}

We have noted in Section 2.2 that the general economic climate and government economic policies are powerful determinants of the results of globalisation. Economic policy itself invariably has social and political determinants. Is Collier (1998) correct when he argues that it is possible that in South Africa "the composition of public expenditure may be sufficiently capital-hostile because of the political and social need for redistribution that it causes a capital exodus"?

In South Africa the government introduced its growth, employment and redistribution (GEAR) strategy. This was basically an output-orientated approach with sound macroeconomic policies matched by redistribution policies. Calitz and Siebrits (2001: 2), in analysing the $2001 / 02$ budget, show that fiscal policy in the 1990s emphasised macroeconomic stabilisation and redistribution at the cost of economic growth and job creation. Since 2000 , however, the budgets have focused directly on economic growth without abandoning the previous objectives. The size of govemment has been halted, and public spending on education and health is higher in South Africa than in other developing countries; as a percentage of GDP it exceeds that of the lower-middle-income group of countries (Calitz, 2000: 588).

Trade liberalisation has resulted in declining income from trade taxes (5.3 per cent of total government income in 1993/94 as against 3.2 per cent in 1999/00) for the central govemment, but this might of course be reversed in due course depending on price elasticities of demand which will determine the rate of growth of imports at the lower tariffs. This decreased reliance on trade taxes was offset by greater dependence on individual company taxes as well as valueadded tax. According to Calitz (2000: 598) the income tax burden on individu- 
als is much higher than in other developing countries, and signifies a tax pressure on skilled individuals who have international mobility. This is a worrying aspect for South Africa. He suggests a move away from income tax toward consumption taxes; these, of course, are regressive although not as much as is usually supposed when lifetime earnings are taken into account. Calitz is concerned about the introduction of residence-based taxation, made in order to respond to the globalisation of economic activity, arguing that this is likely to make South Africans (both individuals and companies) less competitive than their counterparts in other countries which have lower tax rates.

Calitz and Siebrits (2001: 18) refer to a study by the Department of Finance in 1999 which found that the system was broadly progressive, the lowest decile of income earners paying 11 per cent, and the richest decile 30 per cent, of their incomes on these taxes, and that between 1993-97 there was a significant shift in social spending patterns from the higher- to the lower-income groups. What is important, though, is whether this change in social spending actually attains its goals by reaching the poorest groups. This will depend on whether it is absorbed in civil service salaries and wasted on inefficient execution of delivery because of a lack of managerial capacity. For example, since 1995 there has been a substantial real shift in the budgetary allocation towards social services, but this increase in spending has not been matched by a similar improvement in service levels. Much of the increase in provincial education and health spending was the result of salary increases for teachers and health staff. Thus, less was available for teaching materials in the schools and medical supplies at hospitals and clinics. The financial performance of the provinces varies considerably, but as a group they now record an overall surplus. Some provinces, however, are still in a poor financial position, and the same is true of many municipalities. In such instances the standard of services provided has declined. It remains to be seen whether the restructuring of local government and the reduction in the number of municipalities will improve the overall delivery of services. This is something which could significantly affect the poorest households.

\section{Microeconomic Issues}

A growth rate of 5-6 per cent per annum, sustained over a long period and properly managed to produce adequate social services as well as efficient markets, is required if unemployment and poverty are to be reduced substantially. As Hofmeyr (1996) pointed out, in the period 1946-75 rapid sustained economic growth eventually led to substantial vertical mobility on the part of disadvantaged groups and a marked improvement in their economic welfare. South Africa's low growth rate since 1975 has effectively meant that over a quarter of a century has been lost; even economic performance since 1994 has been poor. 
Although the government has won universal praise for its macroeconomic management, it has fallen down on the micro level, particularly with regard to the failure to: curb the rise in crime and corruption; proceed purposefully with privatisation; revise labour legislation in order to increase labour market flexibility; and adopt a large-scale public works programme in order to provide jobs and incomes both in urban and rural areas (Nomvete et al., 1997).

The rigid labour market is consistently shown to be one of the major concerns of foreign investors. In the same view, the proposed minimum wage legislation for domestic service and farm workers - generally considered to be two of the poorest groups - is likely to be counter-productive, leading to increased unemployment and hardship. Market-clearing wages should have been allowed to work, and public works programmes should have been developed on a large scale to mop up unemployment and provide badly needed infrastructure (Maasdorp et al., 1994).

A high rate of economic growth would have meant that a policy of affirmative action would have been far less urgent since there would have been rapid vertical mobility, repeating the 1965-74 experience examined by Hofmeyr (1996). Instead, this policy has led to an enormous loss of scarce human resources through early retirement or emigration which has been encouraged by the perceived discrimination in employment, especially in the public service but also in large corporations. Emigration and early retirement since 1994 have seriously depleted the country's skills base, especially in the public sector. Self-declared emigration is generally regarded as a significant underestimate of the situation. In the context of serious skill shortages this is a trend which the country cannot afford: an efficient economy demands the most efficient management possible. The brain drain covers all race groups and, all told, it is a serious constraint to economic growth: between $15-20$ per cent of resignations in 2000 were due to emigration!

Other well-documented concerns of investors relate to crime, taxation and social policies, which are all areas in which the government could introduce reforms. However, it is also clear that continued high levels of inequality are worrying to investors, and that these levels need to be reduced if FDI is to be attracted. The government has recognised that the private sector is the prime force for economic growth as well as for wealth and employment, creation. This process would be enhanced were the government to focus more directly on economic growth as the top priority, allow the private sector to concentrate on business expansion without constant changes to labour and taxation legislation, and then regulate the proceeds of economic growth so as to influence social welfare. 
Expanded investment in education and the maintenance of a sound system are basic to a high rate of economic growth for South Africa. Unfortunately, the government has attempted to introduce dubious reforms far too quickly, in the process losing thousands of experienced teachers especially in science and mathematics. The same has happened throughout the civil service, and the entire legal system as well as other important economic institutions have become increasingly inefficient (CDE, 2001: 20).

An unexpected development since 1994 has been the adoption of a seriously flawed policy towards gambling. Provision has been made for the granting of up to 40 casino licences nationwide, and this is much more than the economy can sustain. In recent months there have been an increasing number of press reports pointing to the adverse effects on poor households of expenditure on garnbling (particularly on lotteries and casinos). Incomes of poor households have been put under increasing pressure as this expenditure is diverted from basic items such as foodstuffs, clothing and footwear.

\section{The Rural Poverty Problem}

Who are the real poor in South Africa? In general they do not include those in the wage economy, and certainly do not include members of trade unions. Neither do they include everyone in the informal sector: by definition, as the unrecorded sector, this contains such lucrative illegal activities as drug lordism and car-theft syndicates. Some people in the informal sector, in fact, are quite wealthy. Nevertheless, one would expect that much of the poverty at the urban end is found among the openly unemployed as well as individuals in marginal activities in the informal sector, street children and the like, while in rural areas it would consist of households in districts with poor resource endowments, environmental degradation, and low agricultural yields.

An HSRC researcher, ODonovan, argues that poverty is being sustained by a changing job market and the unintended consequences of development initiatives". He talks of a geographical "trap" within which poverty is entrenched. The trap is created by the interaction of three factors: the changing employment profile, government spending and reduced migration. The professional, technical and managerial categories are the ones for which there is increased demand, but employment prospects are declining for unskilled and semi-skilled labour which faces a falling demand. Thus, poorly trained individuals will increasingly become peripheral to the formal economy as will regions that act as reservoirs of unskilled labour. These areas coincide with the former homelands.

This appears to be bome out by Bhorat $(2001: 22)$ who found that urban employment increased by approximately the same number as rural employment de- 
creased. Thus, jobs were redistributed away from nural towards urban areas. This might be in part because of the withdrawal of industrial decentralisation incentives but also in part to trade liberalisation which forced marginal rural firms either to close or to relocate in order to remain competitive. However, it might also have been due to drought and other causes of rural-urban migration.

Whereas a high economic growth rate could have countered impoverishment, the only avenues left for alleviating the situation in these areas are migration and government redistributive spending. However, O'Donovan ${ }^{3}$ finds that rates of migration from the homelands appear low, and that State spending by way of the Reconstruction and Development Programme (RDP) has resulted in an urban bias (well known in development economics) whereby the urban poor receive more than those in rural areas. This is a direct contradiction of their relative needs: the rural population has the greatest need for improved services because its level of deprivation is higher than that in the metropolitan and urban areas. However, RDP expenditure benefits the poor in the developed rather than in rural areas, especially the former homelands where a high proportion of the population is accounted for by poorly educated people and females. O' Donovan argues that there appears to be a change in the basis for RDP spending - away from greatest need to an emphasis on positive rates of retum on the investment.

In view of the arguments of O'Donovan and Bhorat, it is instructive to refer to a study (Antrobus et al., 1999) in the Maluti District of the Eastern Cape. According to this study, the economics of commercial agriculture suggests that the real development opportunities are not to be found in this sector. Rather, there is a need for a new path for economic development and rural resource reconstruction. Eco-tourism offers a more promising alternative, while other new stimuli would be derived from road construction projects (labour intensive where possible) and public works programmes focused on the eradication of exotic species and the combating of soil erosion.

In former commercial areas which had been bought out many years ago by the Transkei government and redistributed to local residents, arable lands had not been cultivated for some time. In another area which previously produced large volumes of wheat and maize as well as being important in the dairying and beef industries, the decline of output is attributable mainly to the fact that the former commercial farms are being held on leasehold. Thus, the farmers are reluctant to invest in improvements. The decision by the then government to lease out the farms was good neither for securing collateral for bank loans nor for inculcating a commitment to commercial production. Many of the lessees were affluent traders or bus owners with good political connections for whom a farm would be a mere sideline on which a few cattle could be kept. While the lessees were meant to have been carefully selected, not all were screened, there was an ele- 
ment of political patronage, and some are not serious about farming. However, most did not have sufficient capital anyway to start commercial farming operations, and are in deep financial trouble.

The communal areas contain some of the best land for maize production in EastGriqualand, but are underutilised. It is very difficult for small farmers to establish themselves because of the small margins. Yet, new dwellings are very evident in the communal areas of the district, but they have been constructed with funds received from household members employed in the towns and from pensions, not from farming income. Agriculture does not appear to be a highly esteemed occupation, and the population consequently is not geared to commercial production. It is difficult to generate the equivalent of a monthly pension from a small piece of land, and residents would rather devote their expenditure to other items than to farm inputs. Because food is relatively cheap, it is not worth the labour time and effort to grow crops. In many parts of the Transkei, therefore, agriculture is non-existent, and maize is grown more for cultural than for subsistence reasons. Agricultural land is largely unused; land is valued not for its title but for its security (social security and cheap housing), and consequently it is treated as a free good. The area is a rural dormitory for those dependent on income transfers from the urban areas.

The economics of agriculture, therefore, militates against development of this sector. All efforts on the part of non-governmental organisations and development agencies tend to peter out after a while because the time inputs necessary from farmers are not commensurate with the benefits derived. The development challenge is how to get people off the land or else encourage them to use it productively. A land tax and economic incentives could be appropriate policy instruments, but a focus on agriculture would prove of only limited usefulness in an environmentally sustainable resource development programme in the Maluti District. Consequently, the potential of other economic sectors must be investigated.

The entire stretch of the Drakensberg in the district remains to be exploited for eco-tourism development which could act as a trigger not only for rural resource reconstruction but for improving the quality of life for local communities. Given this untapped potential, linkages need to be made between agriculture and tourism. Agriculture needs to move away from the traditional focus on maize towards the development of small-scale production to supply niche foods such as fresh, organically grown vegetables and hormone-free meat to tourist accommodation establishments which need to be built in the area. Moreover, export markets arising from changing global consumer tastes could be supplied: there is a growing trend towards the use of alternative health products in the rich countries of the northern hemisphere. This is manifested in increased consump- 
tion of organically produced foodstuffs, hormone-free meat and natural medicines. In all these lines there is potential for an imaginative approach to the transformation of agriculture. Tunnel farming is labour-intensive, and current moves in South Africa to involve rural communities in some former homeland areas in organic agriculture and floriculture hold out some hope for helping them out of the poverty trap.

\section{Policy Choices}

South Africa has an open economy, measured by merchandise exports and imports together as a proportion of GDP. The figure was 47.6 per cent in 1998 (World Bank, 2000: 252-3; 2001, 312-3), which puts South Africa in the same category as Britain, Kenya, Nigeria, New Zealand, Germany, France and Spain. Thus, as Fields (2000: 5 ) points out, South Africa does not have a choice: if it is to prosper, it must export more. It cannot become prosperous by selling to itself. If South Africa is to attract FDI, foreign enterprises must have an incentive to employ South African labour. The country must make itself attractive to manufacturing investment, and can do so through high productivity, good labour relations, and high rates of retum on the investments. Conversely, its efforts will be impeded by "excessively restrictive labour practices, the labour hassle factor and unsafe living environment for business executives and their families" (Fields, 2000: 5).

Fields (2000: 4) points out that no study has found zero elasticity of employment; most have found a wage elasticity of demand for labour of -0.5 to -0.7 , meaning that for each percentage point increase in wages there is roughly a onehalf point reduction in employment. Thus, the policy choice for South Africa in reducing absolute poverty is to raise the earnings of the employed or to raise employment by holding down the growth of real wages, i.e., between lower real wages but more jobs, or higher real wages but fewer jobs. Wood (2000:9) also points to hard policy choices which need to be made between increased wage inequality and increased unemployment. Surely, however, for those in absolute poverty and without jobs, the choice is clear: lower real wages but more jobs.

The policy choice is indeed hard for the government since it was political pressure which gave rise to the economically ill-conceived labour legislation of the last few years. This has offered trade union members employment conditions superior to those in other countries with similar labour market conditions and at similar levels of economic development, as well as wages far in excess of market-clearing levels. By making it extremely difficult to dismiss or retrench workers, it has discouraged firms - small and large - from taking on more staff. For foreign companies there is no intrinsic reason to invest in South Africa when flexible labour markets are operating in developing countries (including 
neighbouring states in the region). It is largely for this reason that Asian companies are locating apparel and textile industries in Lesotho and Namibia rather than South Africa.

Labour market rigidity has meant that a key factor market is unfree at a time when the other factor market - capital - has been liberalised through general macroeconomic reforms. Yet, liberalisation of the one without the other would not achieve the desired goals of stimulating investment, creating employment, and helping to reduce the income gap and raise the standard of living of the poorest. Labour market policy is antithetical to the interests of the unemployed masses, for whom there has been a negligible economic trickle-down effect from political change and globalisation.

The fact that the market mechanism is prevented from operating allows trade union membership, although accounting for only 20 per cent of the total economically active population, to provide guaranteed entry into a club of urban insiders protected against competition in the labour market from outsiders (Nomvete et al., 1997: 27-32). A new dualism, then, can be said to have emerged between union members and the mass of the labour force who are unorganised. The prime interest of the labour force as a whole, including those who are unemployed and underemployed, is for job expansion. Conversely, the interest of the unionised workforce is to protect itself by eliminating competition in an open labour market.

A Standard Bank report (2000) has pointed out that there have been important structural changes in the economy in recent years. First, the relative share in GDP of the primary and secondary sectors has declined while that of the tertiary sector has grown. Secondly, restructuring and technological change have led to an increased demand for skilled and a declining demand for unskilled labour. Employer demand for skills exceeds supply, creating a constraint to economic development. The report (Standard Bank, 2000) finds that trade generated 60, 436 net jobs between 1993-97 but that these structural changes mean that the continued ability of trade to generate employment is weakening.

However, both the weakening of trade as an employment-generating factor and the growing skills gap are influenced by South Africa having effectively pricing itself out of the market for labour-intensive industry. Perhaps South Africa would not be able to compete with the very low-wage countries of China and South-east Asia, but after 1994 foreign companies were clearly interested in investing in the country. Were it not for negative perceptions about the general labour environment, there is little doubt that the country could have attracted FDI into manufacturing industry at both the capital-intensive and labourintensive ends. The skilled and highly skilled as a proportion of the labour force 
increased from 38 per cent in 1970 to 57 per cent in 1997/98, while the share of unskilled workers declined from 62 per cent to 43 per cent over the same period (Abedian \& Antonie, 2001). Even though there is a skills shortage, this skills mix implies that South Africa is better placed than other countries in Africa to attract capital intensive industry, while at the same time the excess supply of unskilled labour is favourable for the attraction of labour-intensive industry.

For the urban unemployed the equivalent to introducing innovative thinking into Transkei agriculture would be to open up the labour market in order to attract investment at the lower end and create a climate in which firms, in all sectors of the economy, are willing to take on additional staff. For the unemployed and underemployed, both nural and urban, it is government policy, not globalisation, that limits their opportunities for escaping from poverty.

\section{CONCLUSION}

The Governor of the South African Reserve Bank recently stated that "even the staunchest critics must agree that globalisation is inevitable and that it can be a strident force for generating wealth and reducing poverty"4. He also stated that South Africa's responses to globalisation needed to be managed, pointing to the grouping of countries into economic and political blocs in order improve their bargaining power in world fora.

South Africa is part of the African group of countries which have been cooperating in formulating a negotiating position in the next round of WTO negotiations. The policy of governments should be to improve the present world trading system under the WTO in order to ensure that it works for the poor. Inequities in the existing international trading system need to be corrected. In particular, protectionism and subsidies, especially in agriculture, in developed countries need to be abolished. These barriers are most damaging in areas of key importance for poverty reduction in developing countries, namely, agriculture, textiles, and clothing. It is along these lines that South Africa ought to concentrate its arguments. The alternative is a situation in which richer countries dominate the rest or else make bilateral trade deals among themselves which exclude poor countries. A retreat into trade protectionism would hit the world's poorest countries, and jettisoning the system is not the answer. As The Economist (11 December 1999) points out, trade is about greater competition. Thus, it weakens the power of vested interests, creates greater opportunities for the masses rather than privileges for the few, and allows more countries to join the East Asian NIEs which have been the ones which have closed the gap on the west and raised the standards of living of their populations. 
For South Africa to close the gap, it will need to overcome its weak points in the global competition ratings. There is a dichotomy between its sound macroeconomic policies and some of its micro policies. Failure to address the issues would bear out Collier's (1998) interpretation, namely, that socio-political factors conceivably are the real driving forces and that South Africa is one of two African economies in which redistributionist policies might cause public expenditure to be capital-hostile and repel private capital. This would mean that South Africa would not attract the FDI it needs in order to achieve robust economic growth and shrink absolute poverty. The best redistributive medicine, though, would be through higher economic and employment growth, and these require FDI. Without them, the dual economy - contrasting those in poverty and those who are not - would persist.

\section{END NOTES}

1 A survey by P-E Corporate Services quoted in Sake-Rapport, 25 March 2001 .

2 M. O'Donovan in a leader page article in Business Day, 29 March 2000.

3 Ibid.

4 Business Report, 15 August 2001.

\section{REFERENCES}

1 ABEDIAN, I. \& ANTONIE, F. (2001) "Contemporary Challenges Facing South African Business in a Globalising Economy", Paper delivered to the 4th Annual Conference, Centre for the Study of African Economies, Oxford.

2 ANTROBUS, G.; MAASDORP, G.; MANDER, M.; MOWAT, S. \& MYERS, G. (1999) "Flight of the Ducks: Environmentally Sustainable Economic Development in the Matatiele Area", Pretoria: Department of Environmental Affairs and Tourism.

3 BHORAT, H. (2001) "Employment trends in South Africa", Occasional Paper No. 2. Johannesburg: Friedrich Ebert Stiftung.

4 BMR (2000) "The South African Provinces: Population and Economic Welfare Levels, 2000", Research Report No. 276, Pretoria: Bureau of Market Research, University of South Africa.

5 CALITZ, E. (2000) "Fiscal Implications of the Economic Globalisation of South Africa", South African Joumal of Economics, 68(4), 564-606.

6 CALITZ, E. \& SIEBRITS, K. (2001) "After the Pain the Gain? An Assessment of the 2001/2002 Budget", ABSA Economic Perspective, Special Edition, April. 
7 CDE (2001) "Why is South Africa Failing to get the Growth and Jobs that it Needs?" Johannesburg: Centre for Development and Enterprise.

8 COLLIER. P. (1998) "Globalisation: Implications for African Economic Management", Draft Paper. Washington, D.C.: World Bank.

9 ELLISON, P.A., PILLAY, P.N. \& MAASDORP, G.G. (1975) "The Poverty Datum Line Debate in South Africa: An Appraisal", Occasional Paper No. 4. Durban: Department of Economics, University of Natal.

10 FEI, J.C.H. \& RANIS, G, (1964) Development of the Labour Surphus Economy Homewood, Ill: Richard D. Irwin, Inc.

11 FIELDS, G. (2000) "The Employment Problem in South Africa", Trade and Industry Monitor, 16, 3-6.

12 HIGGINS, B. (1968) Economic Development, London: Constable and Co. Ltd.

13 HIRSCHMAN, A.O. (1958) The Strategy of Economic Development, New Haven: Yale University Press.

14 HMSO (2000) "Eliminating World Poverty: Making Globalisation Work for the Poor", White Paper on International Development. London: The Stationery Office Ltd.

15 HOFMEYR, J. (1996) "The South African Labour Market: Historical Trends" in Innes, D. (ed.), The South African Labour Market: An Analysis of Trends, Challenges and Policy Implications. Unpublished Paper. Cape Town: Africa Institute for Policy Analysis.

16 HORWOOD, O.P.F. (1964) "The Social Framework of Economic Development in a Dual Society. The Case of South Africa" in Holleman, J.F. (ed.), Problems of Transition, Pietermaritzburg: Natal University Press.

17 HORWOOD, O.P.F. (1965) "Economic Balance, Dualism and Growth, with applications for the South African Economy", South African Joumal of Economics, 33(3), 171-192.

18 ILO (1972) Employment, Incomes and Equality: A Strategy for Increasing Productive Employment in Kenya, Geneva: International Labour Office.

19 LEWIS, W.A. (1954) "Economic Development with Unlimited Supplies of Labour", The Manchester School of Economic and Social Studies, May, 139-191.

20 MAASDORP, G. (1991) "The Landlocked Countries: Swaziland" In Konczacki, Z.A.; Parpart, J.L. and Shaw, T.M. (eds.), Studies in the Economic History of South Africa, Volume Two: South Africa, Lesotho and Swaziland, London: Frank Cass \& Co. Ltd.

21 MAASDORP, G \& HUMPHREYS, A.S.B. (eds.) (1975) From Shantytown to Township, Cape Town: Juta.

22 MAASDORP, G.J. HOFMEYR, N. WILKINS, I. ABEDIAN, B. STANDISH \& DONALDSON, A. (1994) "Special Employment Projects in South Africa". Report prepared for the Urban Foundation. Durban: Economic Research Unit, University of Natal. 
23 MEIER, G.M. (1989) Leading Issues in Economic Development, New York: Oxford University Press.

24 NOMVETE, B.D., MAASDORP, G.G. \& THOMAS, D. (1997) Growth with Equity, Cape Town: Africa Institute for Policy Analysis.

25 STANDARD BANK (2000) "The Impact of the Structural Change of the South African Economy on Labour" Editors' Brief, September. Johannesburg: Economics Division, Standard Bank.

26 STANDARD BANK (2001) "Accelerating Growth in South Africa". Editors' Brief, Q1. Johannesburg: Economics Division, Standard Bank.

27 STATISTICS SOUTH AFRICA (2000) Measuring Poverty in South Africa Pretoria: Statistics South Africa.

28 TODARO, M.P. (1971) "Income Expectations, Rural-Urban Migration and Employment in Africa", International Labour Review, 104 (5), 39195, 411-13.

29 WOOD, A. (2000) "When and Why does Globalisation Increase rather than Reduce Labour Market Inequalities in Developing Countries?" Trade and Industry Monitor, 16, 7-9.

30 WORLD BANK (2000) Entering the 21st Century: World Development Report 1999/2000, New York: Oxford University Press.

31 WORLD BANK (2001) Attacking Poverty: World Development Report 2000/2001, New York: Oxford University Press. 